\title{
Impact of high-energy diets on the rumen environment and digital cushion in confined cattle ${ }^{1}$
}

\author{
Nicolas C. Tavares², Antônio A. Barbosa² (D), Rogério F. Bermudes², \\ Sandra M.E.F. Rechsteiner ${ }^{2}$, Luis A.X. Cruz ${ }^{2}$, Fabio Raphael P. Bruhn ${ }^{3}$, \\ Paula M. Silva ${ }^{2}$ and Charles F. Martins ${ }^{2 *}$ (D)
}

\begin{abstract}
Tavares N.C., Barbosa A.A., Bermudes R.F., Rechsteiner S.M.E.F., Cruz L.A.X., Bruhn F.R.P., Silva P.M. \& Martins C.F. 2019. The impact of high-energy diets on the rumen environment and digital cushion in confined cattle. Pesquisa Veterinária Brasileira 39(12):970-977. Universidade Federal de Pelotas, Campus Capão do Leão, Av. Eliseu Maciel s/n, Capão do Leão, RS 96900-010, Brazil. E-mail: martinscf68@yahoo.com.br

This study aimed to identify gross and microscopic changes, caused by high-energy diets, in the rumen environment and hoof of confined beef cattle. The study sample comprised 40 confined heifers (Bos taurus) with no disease history divided into four experimental groups using different diets: Group 1 (D1, control), 48:52 forage:concentrate ratio; Group 2 (D2), 30:70 forage:concentrate ratio; Group 3 (D3), 30:70 forage:concentrate ratio + sucrose; Group 4 (D4), 100\% concentrate. All animals underwent clinical examination, assessment of ruminal fluid $\mathrm{pH}$ and lameness, and sample collection after slaughter for histopathology of the hoof laminae and digital cushion and ruminal tissue. All dependent variables of the study were compared using the SPSS 20.0 statistical software. The variables that did not show normality (HR, RM, ST, and CRT) were compared with application of the Kruskal-Wallis test followed by the Dunnet's multiple comparison test. All other variables were submitted to analysis of variance (ANOVA) followed by Tukey's test. The different diets had an impact on the rumen environment $(p<0.05)$ of the heifers assessed, with momentary general depression in the first $12 \mathrm{~h}$ after sucrose induction (D3), as well as mild clinical signs in D4. The animals in D3 and D4 presented lower motility $(p<0.05)$ and ruminal $\mathrm{pH}(p<0.01)$ than those in D1. Of the 40 heifers, $27.5 \%(n=11)$ showed gross lesions in the epithelium of ruminal pillars, whereas $22.5 \%(n=9)$ of those in D3 and D4 presented these lesions. Sole corium thickness varied between heifers in D3 compared with those in D1 and D2 $(p<0.05)$. Therefore, high-energy diets, as used in this study, alter some clinical parameters and the rumen environment, causing lesions in the rumen mucosa, and of lesser intensity, in the hoof corium and laminae, suggestive of laminitis.
\end{abstract}

INDEX TERMS: High-energy diets, rumen environment, digital cushion, confined cattle, acidosis, hoof, histology, laminitis, confinement.

RESUMO.- [0 impacto de dietas de alto valor energético sobre o ambiente ruminal e o tecido digital em bovinos confinados.] 0 objetivo deste trabalho foi identificar alterações macroscópicas e microscópicas provocadas por dietas de alto

\footnotetext{
${ }^{1}$ Received on July 30, 2019.

Accepted for publication on August 6, 2019.

${ }^{2}$ Universidade Federal de Pelotas (UFPel), Campus Capão do Leão, Av. Eliseu Maciel s/n, Capão do Leão, RS 96900-010, Brazil. *Corresponding author: martinscf68@yahoo.com.br

${ }^{3}$ Departamento de Veterinária Preventiva, Faculdade de Veterinária, Universidade Federal de Pelotas (UFPel), Campus Capão do Leão, Av. Eliseu Maciel s/n, Capão do Leão, RS 96900-010.E-mail: fabio_rpb@yahoo.com.br
}

valor energético no ambiente ruminal e casco de bovinos de corte (Bos taurus) em confinamento. Foram utilizadas 40 novilhas mantidas em confinamento, sendo divididas em 4 grupos experimentais: Grupo D1(controle) - 48\% de volumoso e 52\% de concentrado; Grupo D2 - 30\% de volumoso e 70\% de concentrado; Grupo D3 - 30\% de volumoso e 70\% de concentrado + sacarose; Grupo D4 - 100\% de concentrado. Foi realizado exame clínico dos animais, avaliação do pH ruminal, da claudicação, além de coletas de amostras post-mortem para análises histopatológicas da região laminar do casco, coxim digital e do rúmen. Todas as variáveis dependentes do estudo foram comparadas por meio do software estatístico 
SPSS 20.0. As variáveis sem normalidade (FC, MR, Tc e TPC) foram comparadas pelo teste de Kruskal Wallis, seguido pelo teste de comparação múltipla de Dunnet. Todas demais foram submetidas a análise de variância (ANOVA), seguida pelo teste de Tukey. Foi observado impacto das distintas dietas ao ambiente ruminal $(p<0,05)$. Os grupos D3 e D4 exibiram menor motilidade $(p<0,05)$ e $\mathrm{pH}$ ruminal $(\mathrm{p}<0,01) .27,5 \%$ $(\mathrm{n}=11)$ dos animais tiveram registros macroscópicos de lesões no epitélio dos pilares ruminais enquanto que os submetidos às dietas 3 e 4 foi observada ocorrência de $22,5 \%(n=9)$ de lesões macroscópicas no rúmen. As espessuras do córium solear variaram entre os grupos que receberam a indução de sacarose em relação ao grupo controle e novilhas alimentadas com a dieta $2(p<0,05)$. Sendo assim dietas com elevada densidade energética, na condição em que foi empregada, alteraram alguns parâmetros clínicos e o ambiente ruminal, provocando lesões na mucosa do rúmen e de pouca intensidade no córium e tecido laminar, sugestiva de laminite.

TERMOS DE INDEXAÇ̃̃O: Dietas, alto valor energético, ambiente ruminal, tecido digital, bovinos confinados, acidose, casco, histologia, laminite, confinamento.

\section{INTRODUCTION}

Beef cattle raising is an activity of great importance in the Brazilian economy. Concerning variable costs, the intensive system presents considerably higher expenses, mainly because of investment in animal feed. While providing concentrate feed increases production costs, increasing the dietary concentrate ratio improves animal performance as it increases daily weight gain and reduces termination time. Thus, confinement enables larger production in the same physical space, ensuring high system profitability (Missio et al. 2009).

Inclusion of carbohydrate-rich foods that are easily metabolized in cattle diet may lead to development of metabolic changes such as sub-acute rumen acidosis (SARA) (Ortolani et al. 2010). This metabolic disorder, in addition to causing a sharp decline in ruminal motility, ingestion and rumination, can also affect, secondarily, the locomotor system (Mulling \& Greenough 2006).

The precise etiology and pathogenesis of foot disorders in ruminants are not fully known. Dietary energy density may be a predisposing factor as a cause of locomotion disorders. Knowledge of the mechanisms that lead to these disorders has been mainly described empirically, and is often extrapolated from equine species. However, there are anatomo-functional differences between the two species, such as absence of secondary dermis and epidermis in bovines, with the laminar region occupying only the distal half of the third phalanx, being smaller when compared with that of horses (Greenough 2007). Thus, the area of adherence of the phalanx to the coronary band through the laminar region is much smaller in cattle compared with horses (Lischer et al. 2002). Moreover, the fact that horses are monogastric and cattle are polygastric (ruminants) does not allow a perfect comparison between the two species.

To date, scientific studies have addressed the impact of nutrition on the cervical/laminar region, but there is lack of information on the impact on the health of the digital cushion, especially when inflammatory systemic events are present in the laminae and corium of the digital cushion of cattle submitted to increased-grain diets. This information is important and needs to be further studied, as digital cushion depletion is associated with body condition score, as well as with the incidence of sole ulcers and white line disease (Bicalho et al. 2009).

Although there is abundance of studies seeking the understandings of hoof structures, digital cushion, and associations between ruminal acidosis and lameness (Lean et al. 2013) on dairy cattle, there are relatively few studies addressing confined beef cattle, in which episodes of SARA occur (Plaizier et al. 2009). Therefore, it is possible that variations in the starch proportions in the diet of beef cattle may promote ruminal damage, with systemic deleterious effects on other tissues, including digit constituents such as the digital cushion, which are associated with pathological events occurring in the corium and laminar tissues. These structural changes in the hoof may predispose cattle to lameness and development of hoof injuries, leading to economic losses (Souza et al. 2006). In this sense, different carbohydrate sources have been used to induce ruminal acidosis with the purpose of studying its dynamics and effects on animal health, providing knowledge about preventive measures that may benefit hoof health. Thus, exogenous sucrose supplementation has been shown to induce rumen acidosis (Ortolani 1995, Maruta \& Ortolani 2002, Krause \& Oetzel 2006).

Understanding the relationship between increased-grain diets with integrity of the hoof wall and the support function offered by the digital fat pad through clinical criteria and gross and microscopic anatomical changes may be relevant in maintaining the hoof health of confined beef cattle. Thus, based on what has been previously exposed, this study focused on identifying the gross and microscopic changes caused by high-energy diets in the rumen environment and hoof of confined beef cattle.

\section{MATERIALS AND METHODS}

The experiment was conducted in the municipality of São Lourenço do Sul, Rio Grande do Sul state, in a commercial farm and slaughterhouse that raised of beef cattle under intensive management. All study procedures were approved by the Animal Experimentation Ethics Commission (CEEA) of the "Universidade Federal de Pelotas" (UFPel) under protocol no. 0105185/2017. The cattle were confined in barns, in $6 \times 7 \mathrm{~m}$ collective stalls, totaling $42 \mathrm{~m}^{2}\left(4.2 \mathrm{~m}^{2} /\right.$ head), with ceiling height of $6 \mathrm{~m}$.

Forty heifers (Bos taurus taurus), 80\% Angus and 20\% Hereford, homogeneously distributed between groups, aged approximately 18 months, with average initial weight of $341 \pm 57.13 \mathrm{~kg}$ composed the study sample. The following inclusion criteria were used: I) no history of disease; II) body condition score (BCS) between three and four on a scale from zero to five (Nicholson \& Butterworth 1986).

The animals were divided into four experimental groups of 10 animals each using different diets, and all of them were clinically healthy with no history of systemic disease or hoof lesions: Group 1 (D1, Control) 48:52 forage:concentrate ratio; Group 2 (D2) 30:70 forage:concentrate ratio; Group 3 (D3) 30:70 forage:concentrate ratio + sucrose; Group 4 (D4) 100\% concentrate (Table 1). The amount of sucrose supplied was calculated based on the technique described by Ortolani (1995), according to equation $\mathrm{Y}=1057+43.1 \mathrm{x}$ LW 0.75, where: $\mathrm{Y}=$ amount of sucrose expressed in grams, LW = live weight in kilograms, and $\mathrm{LW}^{0.75}=$ metabolic weight. The result obtained from this formula was decreased by $15 \%$, as 
performed by Maruta \& Ortolani (2002), aiming to minimize risks to animal health.

The heifers underwent an adaptation period of 15 days prior to study commencement (except those in D4). After this period, the cattle received the treatment diets for 45 days, totaling two months of confinement. The feed provided was weighed daily and always adjusted to allow 5-10\% leftovers, which were later weighed and recorded daily before the first meal of the next day (Campos et al. 2016).

Animal requirements were determined according to the National Research Council (NRC 1996). Dietary samples were collected weekly for bromatological analysis (Table 2).

At the end of confinement, the animals were sent to pre-slaughter fasting, underwent general clinical examination, and had the ruminal fluid $\mathrm{pH}$ measured individually in a squeeze chute. In animals receiving sucrose in the diet (D3), the examinations were performed $24 \mathrm{~h}$ after induction.

General clinical examination of the animals included the measuring of heart rate (HR), respiratory rate (RR), capillary refill time (CRT), rectal temperature $\left(\mathrm{T}^{\circ} \mathrm{C}\right)$, skin turgor (ST), mucosal staining (MS), and ruminal motility (RM) as described by Feitosa (2004). Animals that presented results within the reference values according to Feitosa (2004) in the general clinical examination were considered healthy.

A portable pH meter (Noro et al. 2013) was used for the measurement of ruminal fluid $\mathrm{pH}$ in a single collection by the ruminocentesis dorsomedial procedure, conducted in all animals 3 to 4 hours after the last feeding (pre-slaughter fasting) in the afternoon. Animal lameness was evaluated daily throughout the study period in a fenced area located next to the confinement stalls according to the locomotion score characterized by Ferreira et al. (2005).

All animals were weighed and had their body condition score (BCS) evaluated at the beginning and end of the experiment through weighing and visual assessment, respectively, after a 12-hour fasting.

After opening of the digits, the complete digital cushion, the laminar tissue in the distal proximal dorsal region of the claw, the

Table 1. Characterization of animal diets

\begin{tabular}{lcccc}
\hline \multirow{2}{*}{ Feed } & \multicolumn{4}{c}{ Treatment (forage:concentrate ratio) } \\
\cline { 2 - 5 } & $\begin{array}{c}\text { D1 } \\
(48: 52)\end{array}$ & $\begin{array}{c}\text { D2 } \\
(30: 70)\end{array}$ & $\begin{array}{c}\text { D3 } \\
(30: 70)\end{array}$ & $\begin{array}{c}\text { D4 } \\
(0: 100)\end{array}$ \\
\hline Corn silage $(\mathrm{kg} / \mathrm{MS})$ & 3.750 & 2.240 & 2.240 & 0.00 \\
Concentrate $(\mathrm{kg} / \mathrm{MS})$ & 4.050 & 5.440 & 5.440 & 7.425 \\
Dry matter $(\mathrm{kg})$ & 7.800 & 7.680 & 7.680 & 7.425
\end{tabular}

Table 2. Bromatological composition of the experimental diets (\%)

\begin{tabular}{cccc}
\hline \multirow{2}{*}{ Components } & \multicolumn{3}{c}{ Diet (forage:concentrate ratio) } \\
\cline { 2 - 4 } & $\mathrm{D} 1$ & $\mathrm{D} 2$ and D3 & $\mathrm{D} 4$ \\
$(48: 52)$ & $(30: 70)$ & $(0: 100)$ \\
\hline DM & 100 & 100 & 100 \\
OM & 1.20 & 0.75 & 1.75 \\
NDF & 43.25 & 37.73 & 28.54 \\
ADF & 22.35 & 19.42 & 14.54 \\
CP & 8.90 & 9.84 & 11.32 \\
EE & 4.71 & 4.96 & 5.37 \\
TDN & 71.07 & 74.90 & 81.29
\end{tabular}

$\mathrm{DM}=$ dry matter, $\mathrm{OM}=$ organic matter, $\mathrm{NDF}=$ neutral detergent fiber, $\mathrm{ADF}=$ acid detergent fiber, crude $\mathrm{CP}=$ protein, $\mathrm{EE}=$ ether extract, and TDN = total digestible nutrients. coronary dermis, and the sole corium were collected from all digits in the four limbs. The digital cushion fragments were weighed on a precision scale and the volume was determined by immersing it in a beaker containing $20 \mathrm{~mL}$ of water. All digital cushion samples collected were identified using numbered seals previously used as a means of identifying the animals and limbs. The samples were fixed in $10 \%$ formalin solution for further histological processing (Luna 1968).

After cutting the samples in order to remove the areas to be manipulated using histological forceps, the laminar tissue, digital cushion, and rumen samples were processed following the traditional histology methodology, with subsequent embedding in paraffin blocks according to routine technique. Subsequently, $5 \mu \mathrm{m}$-thick histological sections were placed on histological slides and stained using the hematoxylin and eosin (HE) and periodic acid-Schiff (PAS) techniques (Luna 1968).

All dependent variables of the present study were compared between the different treatments (diets) using the SPSS 20.0 statistical software. Variables with normal distribution $\left(\mathrm{T}^{\circ} \mathrm{C}, \mathrm{RR}, \mathrm{pH}\right.$, percentage of ulcerated ruminal areas, sole corium thickness, BCS, average daily gain intake, carcass yield, and weight, volume and proportion of connective, adipose and vascular tissues of the digital cushion) were submitted to analysis of variance (ANOVA) followed by Tukey's test. The variables that did not show normality (HR, RM, ST, and CRT) were compared by Kruskal-Wallis test followed by the Dunnet's multiple comparison test.

\section{RESULTS}

The different diets used in this study affected the rumen environment $(p<0.05)$ of the assessed heifers. Diarrhea was observed in the first $12 \mathrm{~h}$ after sucrose solution administration (Table 3), as well as reduced rumination and momentary general depression in the heifers in D3 and mild clinical signs in those in D4 (Table 4).

Acute and subacute attacks to the digital cushion derived from the consumption of increased-grain diets were not clinically observed, since none of the heifers that received the different diets showed lameness and postural abnormalities.

Differences between the clinical variables tested were observed only between the ruminal clinical parameters (RM and $\mathrm{pH}$ ). Heifers inD3 and D4 showed lower motility $(p<0.05)$ and ruminal $\mathrm{pH}(\mathrm{I}<0.01)$ than those in D1 (Table 4$).$

As the forage:concentrate ratio was changed in the increased-grain diets, more acidic ruminal environments were formed, changing the organ color (Fig.1). Of the 40 beef heifers fed different diets, $27.5 \%(n=11)$ showed gross lesions in the epithelium of ruminal pillars compatible with

Table 3. Percentage (\%) and number (n) of inconsistent stools in the different diets

\begin{tabular}{ccc}
\hline \multirow{2}{*}{ Diet } & \multicolumn{2}{c}{ Diarrhea } \\
\cline { 2 - 3 } & Presence & Absence \\
\hline D1 & $20.0(2)^{\mathrm{a}}$ & $80.0(8)^{\mathrm{a}}$ \\
D2 & $50.0(5)^{\mathrm{ab}}$ & $50.0(5)^{\mathrm{ab}}$ \\
D3 & $100.0(10)^{\mathrm{c}}$ & $0.0(0)^{\mathrm{c}}$ \\
D4 & $70.0(7)^{\mathrm{b}}$ & $30.0(3)^{\mathrm{b}}$ \\
Total \% (n) & $60.0(24)$ & $40.0(16)$ \\
\hline
\end{tabular}

a,b,c Values followed by superscript lower-case letters in the same column statistically differ $(p \leq 0.05)$ by the Fisher's exact test. 
Table 4. Clinical profile $12 \mathrm{~h}$ prior to slaughter of the different diet groups

\begin{tabular}{|c|c|c|c|c|}
\hline Variable & D1 & D2 & D3 & $\mathrm{D} 4$ \\
\hline $\mathrm{T}\left({ }^{\circ} \mathrm{C}\right)^{*}$ & $39.8(0.11)^{a}$ & $39.6(0.08)^{a}$ & $39.9(0.10)^{a}$ & $39.8(0.11)^{\mathrm{a}}$ \\
\hline $\mathrm{RR}(\mathrm{mov} / \mathrm{min})^{*}$ & $49.8(5.96)^{a}$ & $50.8(4.49)^{\mathrm{a}}$ & $60.0(5.01)^{\mathrm{a}}$ & $65.5(4.18)^{\mathrm{a}}$ \\
\hline HR (beat/min)** & $106.5(27.00)^{\mathrm{a}}$ & $100.0(20.00)^{\mathrm{a}}$ & $110.0(11.25)^{\mathrm{a}}$ & $105.0(16.00)^{\mathrm{a}}$ \\
\hline $\operatorname{CRT}(\mathrm{s})^{* *}$ & $2.0(0.25)^{\mathrm{a}}$ & $2.0(1.00)^{\mathrm{a}}$ & $2.0(0.00)^{\mathrm{a}}$ & $2.0(0.25)^{\mathrm{a}}$ \\
\hline $\mathrm{ST}^{* *}$ & $0.0(0.00)^{\mathrm{a}}$ & $0.0(0.00)^{\mathrm{a}}$ & $0.0(0.25)^{\mathrm{a}}$ & $0.0(0.00)^{\mathrm{a}}$ \\
\hline $\mathrm{RM}(\mathrm{mov} / \mathrm{min})^{* *}$ & $3.0(0.25)^{\mathrm{a}}$ & $3.0(1.00)^{\mathrm{ab}}$ & $2.0(0.00)^{b}$ & $2.0(0.25)^{\mathrm{b}}$ \\
\hline $\mathrm{pH}^{*}$ & $6.4(0.17)^{\mathrm{c}}$ & $5.4(0.17)^{\mathrm{b}}$ & $4.5(0.09)^{\mathrm{a}}$ & $5.1(0.05)^{\mathrm{b}}$ \\
\hline
\end{tabular}

$\mathrm{T}\left({ }^{\circ} \mathrm{C}\right)=$ rectal temperature, $\mathrm{RR}=$ respiratory rate, $\mathrm{HR}=$ heart rate, $\mathrm{CRT}$ : capillary refill time, $\mathrm{ST}=$ skin turgor, $\mathrm{RM}=$ ruminal motility, $\mathrm{pH}=$ ruminal fluid $\mathrm{pH}$; * variables with normal distribution described as mean (standard error) compared by ANOVA and Tukey's test, ** variables without normal distribution of means (interquartile interval) compared by Kruskal-Wallis and Dunnet's tests; ${ }^{\mathrm{a}, \mathrm{b}, \mathrm{c}}$ values followed by different letters in the same line are statistically different $(p \leq 0.05)$.
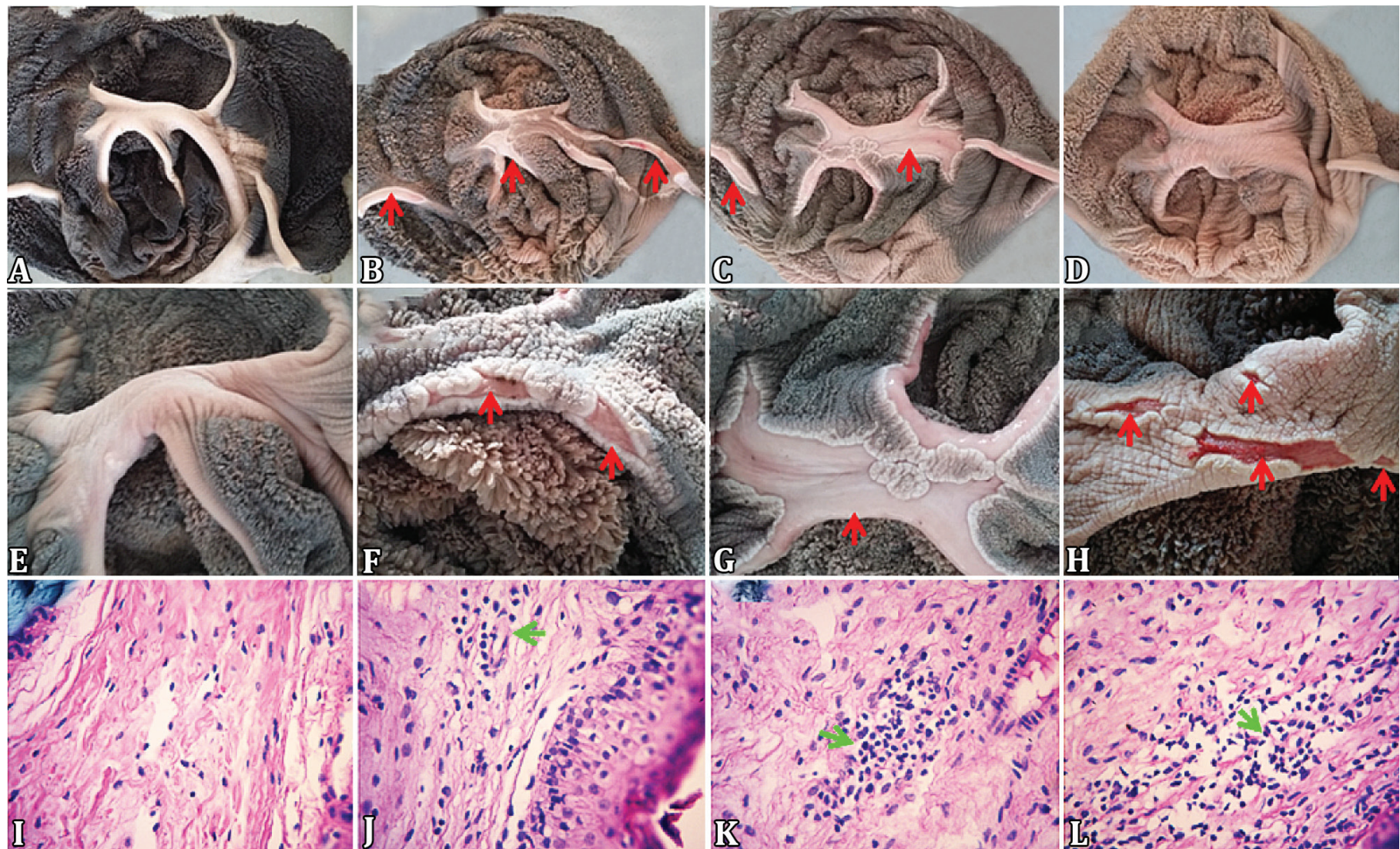

Fig.1. Histology of (A-D) rumen environment, (E-H) rumen pillars, and (I-L) ruminal epithelium. Diets: (A,E,I) control, (B,F,J) unbalanced, $(\mathbf{C}, \mathbf{G}, \mathbf{K})$ unbalanced with sucrose induction, and $(\mathbf{D}, \mathbf{H}, \mathbf{L})$ only concentrate. Ulcers in the ruminal pillars (red arrows) and inflammatory infiltrates (green arrows). (I-L) HE, obj.40x.

development of ruminitis, whereas $22.5 \%(\mathrm{n}=9)$ of those in D3 and D4 presented these lesions. Approximately 40 (D3) to $50 \%$ (D4) of the animals presented ulceration in the ruminal pillars, with average of 5.23 and $2.0 \%$ of the affected area, respectively (Fig.1G,H). Discreet papillary lesion was observed in only one animal in D3.

Histopathology showed preserved rumen papillae, with slight degeneration of keratinized stratified squamous epithelium cells associated with discrete lymphocyte infiltrates in the lamina propria and some papillary vessels with inflammatory cells. The results of this study showed a mild inflammatory reaction of the papillary region in animals in D3 and D4 (Fig.1K,L) compared to the papillary region of those in the other groups. Analysis of lymphocyte infiltration in the supportive connective tissue of the ruminal mucosa indicated a chronic effect of the inflammatory response, with no difference between diets $(p>0.05)$.

Histopathologic differences in the digital tissues $(p<0.05)$ were evident, characterizing a milder form of aggression to the corium and laminar tissue (Table 7, Fig.2). None of the animals, regardless of the diet received, showed congestion, hemorrhage, and detachment of the basement membrane from digital laminar tissue. 
A small number of animals $(n=5,12.5 \%)$ had epidermal cells within physiological standards, with predominance of oval cells perpendicular to the basement membrane. Although $87.5 \%(n=35)$ of the heifers presented secondary epidermal cells with rounded and flattened nuclei, the variation in laminar histology characteristics observed between individuals receiving different levels of dietary concentrate did not contribute to variability between them ( $p>0.05$, Table 5$)$.

Differences were found $(p<0.05)$ when the digits were analyzed separately for cell morphometry. In the left medial front digit, the data presented approximate statistical significance $(p<0.07)$ for epidermal cell morphometry between the groups
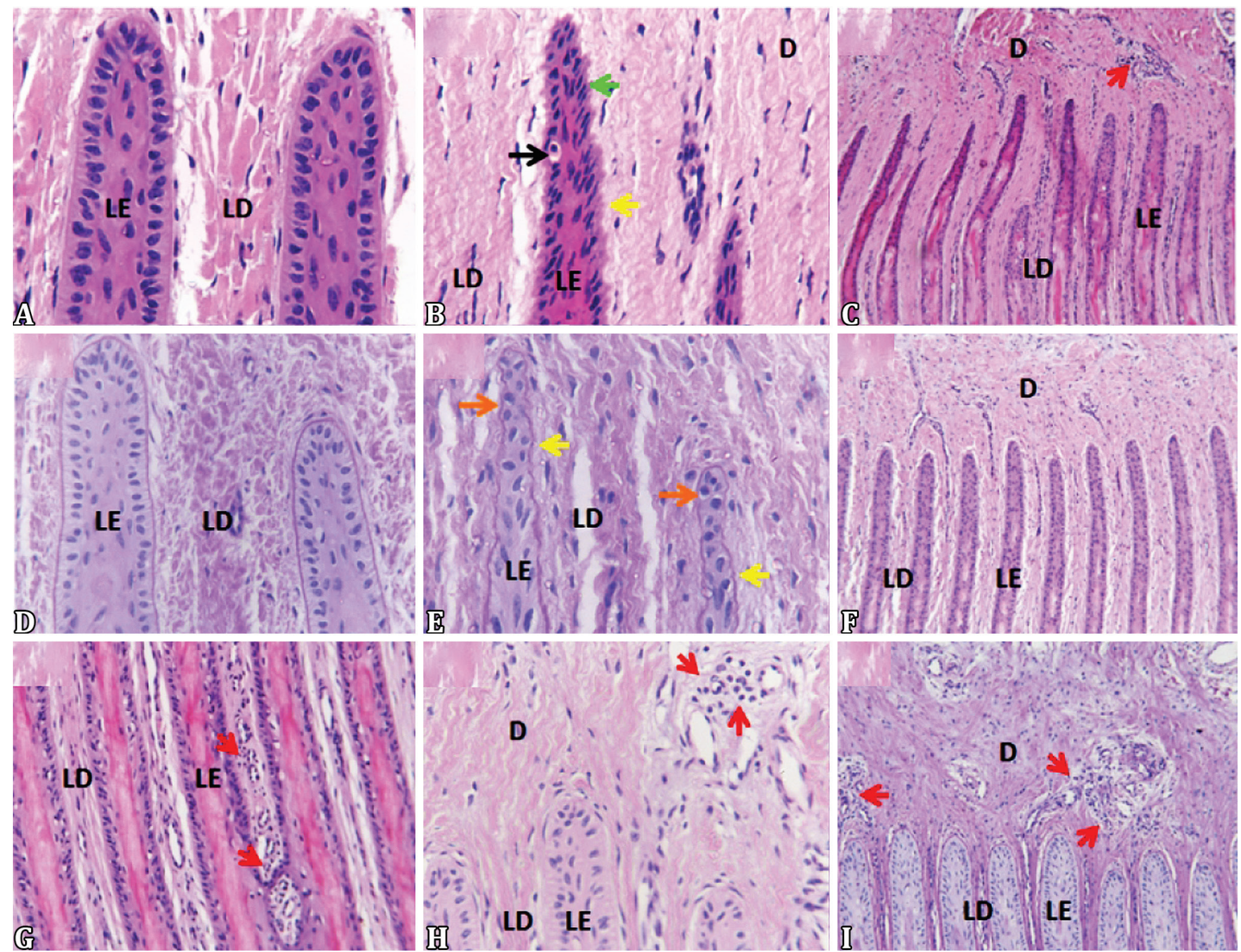

Fig.2. Histology of laminar tissue with dermis (D), dermal (DL) and epidermal (EL) laminae. Inflammatory infiltrates (red arrows), rounded nuclei (orange arrows), elongated and flattened nuclei (green arrows), individual keratinized epidermal cells (black arrows), irregular basal membrane (yellow arrows). (B,C,E) Normal disposition and (A,D,F,H,I) middle third of the dermal and epidermal slides. (A,B,C,G) HE, obj.10x. (D,E,F,H,I) PAS, obj.40x.

Table 5. Cell morphometry on epidermal laminae according to the diet groups

\begin{tabular}{|c|c|c|c|c|c|c|c|c|}
\hline \multirow{3}{*}{ Diet } & \multicolumn{8}{|c|}{ Changes of epidermal cells } \\
\hline & \multicolumn{2}{|c|}{ MLFD } & \multicolumn{2}{|c|}{ LLFD } & \multicolumn{2}{|c|}{ MLHD } & \multicolumn{2}{|c|}{ LLHD } \\
\hline & No & Yes & No & Yes & No & Yes & No & Yes \\
\hline D1\% (n) & $70(7)^{\mathrm{a}}$ & $30(3)^{\mathrm{a}}$ & $80(8)^{a}$ & $20(2)^{a}$ & $40(4)^{\mathrm{a}}$ & $60(6)^{a}$ & $40(4)^{\mathrm{a}}$ & $60(6)^{a}$ \\
\hline D2\% (n) & $20(2)^{\mathrm{a}}$ & $80(8)^{\mathrm{a}}$ & $60(6)^{a}$ & $40(4)^{a}$ & $40(4)^{\mathrm{a}}$ & $60(6)^{a}$ & $20(2)^{\mathrm{a}}$ & $80(8)^{a}$ \\
\hline D3\% (n) & $20(2)^{\mathrm{a}}$ & $80(8)^{\mathrm{a}}$ & $50(5)^{a}$ & $50(5)^{a}$ & $20(2)^{a}$ & $80(8)^{a}$ & $20(2)^{\mathrm{a}}$ & $80(8)^{\mathrm{a}}$ \\
\hline $\mathrm{D} 4 \%(\mathrm{n})$ & $20(2)^{a}$ & $80(8)^{\mathrm{a}}$ & $50(5)^{a}$ & $50(5)^{a}$ & $20(2)^{a}$ & $80(8)^{a}$ & $10(1)^{\mathrm{a}}$ & $90(9)^{\mathrm{a}}$ \\
\hline Total & $32.5(13)$ & $67.5(27)$ & $60.0(24)$ & $40.0(16)$ & $30.0(12)$ & $70.0(28)$ & $22.5(9)$ & $77.5(31)$ \\
\hline
\end{tabular}

MLFD = Medial left front digit, LLFD = lateral left front digit, MLHD = medial left hind digit, LLHD = lateral left hind digit; ${ }^{a}$ values followed by different letters in the same column statistically differ $(p \leq 0.05)$ by the Fisher's exact test. 
Table 6. Occurrence of tapering and stretching in laminar tissue

\begin{tabular}{|c|c|c|c|c|c|c|c|c|}
\hline \multirow{3}{*}{ Diet } & \multicolumn{8}{|c|}{ Laminar tapering and stretching } \\
\hline & \multicolumn{2}{|c|}{ MLFD } & \multicolumn{2}{|c|}{ LLFD } & \multicolumn{2}{|c|}{ MLHD } & \multicolumn{2}{|c|}{ LLHD } \\
\hline & No & Yes & No & Yes & No & Yes & No & Yes \\
\hline D1\% (n) & $90(9)^{a}$ & $10(1)^{\mathrm{a}}$ & $90(9)^{a}$ & $10(1)^{\mathrm{a}}$ & $90(9)^{a}$ & $10(1)^{\mathrm{a}}$ & $70(7)^{a}$ & $30(3)^{a}$ \\
\hline D3\% (n) & $30(3)^{\mathrm{b}}$ & $70(7)^{\mathrm{b}}$ & $70(7)^{\mathrm{a}}$ & $30(3)^{\mathrm{a}}$ & $50(5)^{\mathrm{ab}}$ & $50(5)^{\mathrm{ab}}$ & $30(3)^{\mathrm{a}}$ & $70(7)^{\mathrm{a}}$ \\
\hline $\mathrm{D} 4 \%(\mathrm{n})$ & $40(4)^{b}$ & $60(6)^{b}$ & $50(5)^{\mathrm{a}}$ & $50(5)^{\mathrm{a}}$ & $30(3)^{\mathrm{b}}$ & $70(7)^{\mathrm{b}}$ & $40(4)^{\mathrm{a}}$ & $60(6)^{a}$ \\
\hline
\end{tabular}

MLFD = Medial left front digit, LLFD = lateral left front digit, MLHD = medial left hind digit, LLHD = lateral left hind digit; ${ }^{\mathrm{a}, \mathrm{b}}$ values followed by different letters in the same column statistically differ $(p \leq 0.05)$ by the Fisher's exact test.

Table 7. Means of sole corium thickness (CT) in centimeters (standard error)

\begin{tabular}{cllll}
\hline Digit CT & D1 & D2 & D3 & D4 \\
\hline MRFD & $0.35(0.02)^{\mathrm{a}}$ & $0.33(0.02)^{\mathrm{a}}$ & $0.31(0.03)^{\mathrm{a}}$ & $0.34(0.03)^{\mathrm{a}}$ \\
LRFD & $0.39(0.02)^{\mathrm{a}}$ & $0.37(0.02)^{\mathrm{a}}$ & $0.32(0.03)^{\mathrm{a}}$ & $0.33(0.04)^{\mathrm{a}}$ \\
MLFD & $0.39(0.03)^{\mathrm{b}}$ & $0.33(0.02)^{\mathrm{ab}}$ & $0.28(0.02)^{\mathrm{a}}$ & $0.33(0.03)^{\mathrm{ab}}$ \\
LLFD & $0.38(0.03)^{\mathrm{a}}$ & $0.39(0.02)^{\mathrm{a}}$ & $0.22(0.02)^{\mathrm{a}}$ & $0.34(0.02)^{\mathrm{a}}$ \\
MRHD & $0.29(0.03)^{\mathrm{a}}$ & $0.31(0.27)^{\mathrm{a}}$ & $0.25(0.02)^{\mathrm{a}}$ & $0.29(0.03)^{\mathrm{a}}$ \\
LRHD & $0.32(0.02)^{\mathrm{ab}}$ & $0.35(0.03)^{\mathrm{b}}$ & $0.26(0.02)^{\mathrm{a}}$ & $0.29(0.02)^{\mathrm{ab}}$ \\
MLHD & $0.29(0.02)^{\mathrm{a}}$ & $0.32(0.02)^{\mathrm{a}}$ & $0.24(0.01)^{\mathrm{a}}$ & $0.28(0.02)^{\mathrm{a}}$ \\
LLHD & $0.36(0.02)^{\mathrm{b}}$ & $0.30(0.02)^{\mathrm{ab}}$ & $0.26(0.02)^{\mathrm{a}}$ & $0.32(0.03)^{\mathrm{ab}}$
\end{tabular}

MRFD = Medial right front digit, LRFD = lateral right front digit, MLFD = medial left front digit, LLFD = lateral left front digit, MRHD = medial right hind digit, LRHD = lateral right hind digit, MLHD = medial left hind digit, LLHD = lateral left hind digit; ${ }^{\mathrm{a}, \mathrm{b}}$ values followed by different letters in the same column statistically differ $(p \leq 0.05)$ by the Fisher's exact test.

that received sucrose solution (D3) and fast fermentation (D4) and the Control Group (D1) (Table 6, Fig.2).

The percentage of tapering and stretching of the secondary epidermal laminae varied between the groups with different levels of dietary concentrate $(p<0.05)$. Heifers in D3 and D4 showed higher tapering and stretching of the epidermal laminae in the medial left front digit compared with those in $\mathrm{D} 1$ and in the medial left hind digit between heifers in D4 and those in D1 (Table 6, Fig.2).

Histopathology of the laminar tissue (Table 6) identified presence of mild to moderate stretching and tapering lesions in the epidermal laminae. Sole corium thickness varied between heifers in D3 and D1 and those D2 $(p<0.05$, Table 7). When considering the parallelism between the dorsal surface of the distal phalanx and the innermost line of the epidermal region, no differences were observed between the groups $(p>0.05)$.

\section{DISCUSSION}

The different diets used in the present study had an impact on the rumen environment of the heifers assessed, and those that received the fast fermentation diet (D4) presented mild clinical signs. Gressley et al. (2011) emphasized that integrity of the ruminal epithelium may be relevant for controlling the relation between acidosis and laminitis, as a potential for absorption of rumen toxins. This fact may explain the absence of clinical signs in the digits of the heifers evaluated, as lesions were only observed in the ruminal pillars, a site with lower toxin absorption potential compared with the papillary region.

Sucrose-induced animals (D3) and exclusively concentrate-treated animals (D4) showed lower ruminal motility and fluid $\mathrm{pH}$ compared with those in the control group (D1). Reduction ruminal fluid $\mathrm{pH}$ was due to rumen acid accumulation, which resulted from the fermentation of non-fibrous carbohydrate, especially highly-degradable starch - the main constituent of the cereal grains used in this study (corn and soybean residue). Variation in these ruminal characteristics to levels below 5.6 (ruminal fluid $\mathrm{pH}$ ) and hypomotility are a key features for sub-acute ruminal acidosis (SARA) testing (Krause \& Oetzel 2006). The animals in D1 and D2 received sufficient effective fiber to stimulate chewing and rumination, increasing salivation and, consequently, ruminal buffer, thus reducing fluctuations of ruminal characteristics (RM and $\mathrm{pH}$ ).

The lower thickness observed in the digits of the heifers that received sucrose, despite the evident ruminal and histological parameters, did not characterize phalanx displacement (sinking) in the individuals that showed greater reduction in ruminal $\mathrm{pH}$ and motility, because of the distance between the horizontal planes of the band. The coronary artery and the apex of the distal phalanx extensor process did not vary. These clinical characteristics are expected when there are aggressive episodes of ruminal acidosis confirmed by the presence of lameness, a locomotion condition not evidenced in this study.

Acute and subacute attacks to the digitals resulting from the consumption of increased-grain diets were not clinically observed. Thoefner et al. (2004) validated the experimental induction technique for acute laminitis in cattle based on oligofructose overload. During this experiment, the animals developed signs of acute laminitis confirmed by histopathology; however, the degree of lameness was poorly perceived. 
In another clinical trial using the same laminitis induction technique, the animals presented mild to moderate lameness, and the monitoring time and observers' experience were considered for the highest recorded dynamic assessment sensitivity (Danscher et al. 2009). Therefore, when seeking to identify variations in locomotion in confined animals with mild lameness by observational, interpretive and subjective methods, individual interpretation factors with different criteria are faced, affecting the results and hindering judicious measurements.

The presence of lesions in the epithelium of ruminal pillars due to changes in the forage:concentrate ratio was a very relevant finding, which is compatible with ruminal acidosis. These results were higher than those reported by Vechiato (2009) who analyzed cattle raised under intensive management system and identified a frequency of $11.8 \%$ ruminal acidosis. Although, numerically, the animals in D3 and D4 presented higher percentage of ruminitis, differences between the diets were not observed. It is speculated that if the increase of the sample was considered, significant results could be established, mainly taking into account differences between the ruminal clinical parameters (RM and pH) detected (Table 4, Fig.1).

Lymphocyte infiltrates in the supportive connective tissue of the ruminal mucosa indicate that the mononuclear response was not specific to any diet. This characterizes a stage of inflammatory reaction that usually follows the acute process, indicating recovery, especially when considering the close aggression of the rumen to the slaughter of at least seven days.

Integrity of the ruminal epithelium seems to be relevant to control the association between ruminal acidosis and laminitis. Although neither the acute and sub-acute forms were evidenced in this study for the different diets, histopathological differences in the digital tissues characterized a milder form of aggression to the corium and laminar tissue.

Based on these results, it is beneficial to explain how specific gross lesions occurred in the ruminal pillars considering the generalized acidity in the rumen environment. Some factors may have contributed to the occurrence of more aggressive pillar lesions. Indeed, the region of the rumen pillars presents morphometric and contraction characteristics that allowed more significant contact with acid diet, causing the mechanical damage evidenced. Van Soest et al. (1991) described that the size and number of rumen papillae per mucosal area influence the absorption and neutralization of acids in the rumen. In this context, the region of the ruminal pillars presents smaller morphometric characteristics than the papillary region (size and number), with reduced absorption and neutralization of acids, thus favoring formation of ulcers by acids produced in the rumen (D3 and D4) in contrast with the region covered by papillae.

Regarding cell morphometry, the results of the present study were similar to those reported by Mendes et al. (2013), who compared the dermis-epidermis junction of culling cows with and without lesions indicative of laminitis and found similar percentages in both cases. These results corroborate the pathological findings of the present study because, although the animals in D1 presented changes in cell percentage, relatively higher indices were observed in the laminar tissues of the heifers in D3 and D4, though without statistical difference in the comparison between groups. These changes in cell morphometry reveal that the pathophysiological mechanisms of laminitis may have been grouped into an imbalance of local cell metabolism and the internal ultrastructural integrity of the digit through a moderate predisposing vascular disorder, not resulting in marked breakdown of cellular integrity, and events that culminate in loss of laminar integrity (Stokes 2005).

Higher tapering and stretching of the epidermal laminae in the medial left front digit of animals in D3 and D4, compared with those in D1 and in the medial left hind digit between heifers in D4 and those in D1, are interpretative of chronic variations in laminar tissue. Therefore, by histopathology of the laminar tissue, it was possible to identify presence of mild to moderate stretching and tapering lesions of the epidermal laminae, which are consistent with the laminar histopathologic records described by Thoefner et al. (2004), who identified them in the first $24 \mathrm{~h}$ after the clinical attack of experimental laminitis induction in cattle and after 24 and $72 \mathrm{~h}$ of induction by oligofructose overload (Danscher et al. 2009).

According to Obel (1948), the decrease in the onychogenic substance (nail-forming) would be the cause of stretching of the epidermal laminae, a site that would first suffer the damage caused by laminitis. For Obel, the destabilization caused by stretching lesions could also contribute to the displacement of the distal phalanx inside the hoof, a condition not evidenced in the digits of the heifers in this study.

Parallelism between the dorsal surface of the distal phalanx and the innermost line of the epidermal region did not differ between the groups. In other words, beef cattle fed different diets did not show rotational phalangeal misalignment in any of their digits. These observations corroborate the absence of clinical signs of lameness in the beef heifers throughout the experimental period. According to Pollitt (2008), the dorsal surfaces of the wall and the distal phalanx should form parallel lines in healthy animals. In cases of laminitis, with the fragility of the hoof-phalanx junction, a positive distal angle is formed between these two lines, which increases as the phalanx rotates, pulled by the deep digital flexor tendon. In the studied population, all heifer digits presented zero angulations, which characterize parallelism.

These results point to variation of laminar characteristics between digits, characterizing clinically relevant information that should be considered. Possibly, variation in these morphometric characteristics between digits is associated with biomechanical stress and/or distinct systemic inflammatory response between the individuals in the aforementioned groups. Future studies are needed in order to analyze the differences between digits of confined cattle, taking into consideration the use of systemic biological markers, where the explanation for this may possibly be found.

Presence of low intensity lymphocytes in the laminar tissues characterized inflammatory and degenerative process of low intensity, not compromising the architecture of the heifers regardless of the diet, which certainly would be different in the presence of a large number of erythrocytes and leukocytes, leading to loss of laminar architecture (Paes Leme et al. 2010).

These significant morphometric differences (CT) between the digits of the heifers in this study were not related to the acidosis/laminitis complex, and may be associated with intrinsic (genetic and metabolic) and extrinsic (environmental) factors, which can influence skeleton formation and the process of growth and development. 


\section{CONCLUSIONS}

Although diets with sucrose solution and increased-grain change the clinical profile of confined beef cattle, they promote mild aggression to the corium and laminar tissue and to the integrity of the epithelium, with histological changes suggestive of laminitis.

Ruminal papillary tissue seems to be relevant to control the association between acidosis and laminitis. Therefore, high-energy diets, as used in this study, alter some clinical parameters and the rumen environment, causing lesions in the rumen mucosa and, of lesser intensity, in the hoof corium and laminae, suggestive of laminitis.

Observation of animals submitted to this type of feeding management is relevant and deserves further studies.

Conflict of interest statement.- The authors have no competing interests to declare.

\section{REFERENCES}

Bicalho R.C., Machado V.S. \& Caixeta L.S. 2009. Lameness in dairy cattle: A debilitating disease or a disease of debilitated cattle? A cross-sectional study of lameness prevalence and thickness of the digital cushion. J. Dairy Sci. 92(7):3175-3184. <http://dx.doi.org/10.3168/jds.2008-1827> <PMid:19757545>

Campos A.D.S., Diaz B.L., Rivera E.A.B., Granjeiro J.M., Braga L.M.G.D.M., Frajblat M. \& Stephano M.A. 2016. Guia brasileiro de produção, manutenção ou utilização de animais em atividades de ensino ou pesquisa científica: introdução geral. Ministério da Ciência, Tecnologia e Inovação, Brasília, DF. 39p.

Danscher A.M., Enemark J.M.D., Telezhenko E., Capion N., Ekstrøm C.T. \& Thoefner M.B. 2009. Oligofructose overload induces lameness in cattle. J. Dairy Sci. 92(2):607-616. <http://dx.doi.org/10.3168/jds.2008-1271> <PMid:19164671>

Feitosa F.L. 2004. Semiologia Veterinária: a arte do exame clínico. Roca, São Paulo. 807p.

Ferreira P.M., Carvalho A.U., Facury-filho E.J., Ferreira M.G. \& Ferreira R.G. 2005. Afecções do sistema locomotor dos bovinos. Simpósio Mineiro de Buiatria, Belo Horizonte. 26p.

Greenough P.R. 2007. Bovine Laminitis and Lameness: a hands on approach. Saunders Elsevier, St. Louis. 311p.

Gressley T., Hall M.B. \& Armentano L. 2011. Ruminant nutrition symposium: productivity, digestion, and health responses to hindgut acidosis in ruminants. J. Anim. Sci. 89(4):1120-1130. <http://dx.doi.org/10.2527/ jas.2010-3460><PMid:21415422>

Krause K.M. \& Oetzel G.R. 2006. Understanding and preventing subacute ruminal acidosis in dairy herds: a review. Anim. Feed Sci. Technol. 126(3/4):215-236. <http://dx.doi.org/10.1016/j.anifeedsci.2005.08.004>

Lean I.J., Westwood C.T., Golder H.M. \& Vermunt J.J. 2013. Impact of nutrition on lameness and claw health in cattle. Livestock Sci. 156(1):71-87. <http:// dx.doi.org/10.1016/j.livsci.2013.06.006>

Lischer C.J., Koller U., Geyer H., Mülling C.H., Schulze J. \& Ossent P. 2002. Effect of therapeutic dietary biotin on the healing of uncomplicated sole ulcers in dairy cattle-a double blinded controlled study. Vet. J. 63(1):51-60. <http:// dx.doi.org/10.1053/tvjl.2001.0627><PMid:11749136>

Luna L.G. 1968. Manual of histologic staining methods of the Armed Forces. Institute of Pathology, McGraw, 258p.

Maruta A.C. \& Ortolani L.E. 2002. Susceptibilidade de bovinos das raças Jersey e Gir à acidose láctica ruminal. II. Acidose metabólica e metabolização do lactato-L. Ciência Rural 32(1):61-65. <http://dx.doi.org/10.1590/S010384782002000100011>
Mendes H.M., Casagrande F.P., Lima I.R., Souza C.H., Gontijo L.D., Alves G.E. \& Faleiros R.R. 2013. Histopathology of dairy cows' hooves with signs of naturally acquired laminitis. Pesq. Vet. Bras. 33(5):613-619. <http:// dx.doi.org/10.1590/S0100-736X2013000500011>

Missio R.L., Brondani I.L., Freitas L.D.S., Sachet R.H., Silva J.D. \& Restle J. 2009. Desempenho e avaliação econômica da terminação de tourinhos em confinamento alimentados com diferentes níveis de concentrado na dieta. Revta Bras. Zootec. 38(7):1309-1316. <http://dx.doi.org/10.1590/ S1516-35982009000700021>

Mulling C.K.W. \& Greenough P.R. 2006. Applied Physiopathology of the Foot. Proceedings of the XXIV World Buiatrics Congress, Nice, France. Available at <http://www.ivis.org/proceedings/wbc/wbc2006/mulling.pdf?LA=1> Accessed on Jun. 12, 2018.

NRC 1996. Nutrient Requirements of Beef Cattle: 7th Revised Edition. Subcommittee on Beef Cattle Nutrition, National Academy Press, National Research Council, Washington, 242p.

Nicholson M.J. \& Butterworth M.H. 1986. A Guide to Condition Scoring of Zebu Cattle. International Livestock Centre for Africa, Addis Ababa, Ethiopia. 29p.

Noro M., Sepúlveda P., Cárdenas F., Chihuailaf R.H. \& Wittwer F. 2013. Rumenocentesis dorsomedial: un procedimiento seguro para la obtención de líquido ruminal en vacas lecheras a pastoreo. Arch. Med. vet. 45(1):2531. <http://dx.doi.org/10.4067/S0301-732X2013000100005>

Obel N.1948. Studies on the histopathology of acute laminitis. Almquist and Wiksells Boktryckteri, Uppsala, Sweden, 95p.

Ortolani E. 1995. Induction of lactic acidosis in cattle with sucrose: relationship between dose, rumen fluid $\mathrm{pH}$ and animal size. Vet. Hum. Toxicol. 37(5):462-464.

Ortolani E.L., Maruta C.A. \& Minervino A.H.M. 2010. Aspectos clínicos da indução experimental de acidose láctica ruminal em zebuínos e taurinos. Braz. J. Vet. Res. Anim. Sci. 47(4):253-261.<http://dx.doi.org/10.11606/ issn.1678-4456.bjvras.2010.26823>

Paes Leme F.O., Bonna F.A.B., De Marval C.A., Xavier S.H.N., Santos R.L., Faleiros R.R. \& Alves G.E.S. 2010. Histopathology of the digital laminae from horses with acute induced laminitist reated with ketoprophen, phenylbutazone, and flunixin meglumin. Arq. Bras. Med. Vet. Zootec. 62(2):241-250. <http:// dx.doi.org/10.1590/S0102-09352010000200001>

Plaizier J.C., Krause D.O., Gozho G.N. \& Mc Bride B.W. 2009. Subacute ruminal acidosis in dairy cows: the physiological causes, incidence and consequences. Vet. J. 176(1):21-31. <http://dx.doi.org/10.1016/j.tvjl.2007.12.016> <PMid:18329918>

Pollitt C.C. 2008. Equine Laminitis Current Concepts. Publication No. 08/062, Project No. RIRDC UQ-118A. Queensland, Australia, p.55-60.

Souza R.C., Ferreira P.M., Molina L.R., Carvalho A.U. \& Facury Filho E.J. 2006. Perdas econômicas ocasionadas pelas enfermidades podais em vacas leiteiras confinadas em sistema free stall. Arq. Bras. Med. Vet. Zootec. 58(6):982-987. <http://dx.doi.org/10.1590/S0102-09352006000600002>

Stokes A.M. 2005. The pathophysiology of acute laminitis. Anais do II Simpósio Internacional do Cavalo Atleta, Belo Horizonte, p.83-89.

Thoefner M.B., Pollitt C.C., Van Eps A.W., Milinovich G.J., Trott D.J., Wattle O. \& Andersen P.H. 2004. Acute bovine laminitis: A new induction model using alimentary oligofructose overload. J. Dairy Sci. 87(9):2932-2940.<http:// dx.doi.org/10.3168/jds.S0022-0302(04)73424-4> <PMid:15375054>

Vechiato T.A.F. 2009. Estudos retrospectivos e prospectivos da presença de abscessos hepático em bovinos abatidos em um frigorífico paulista. Master's Thesis, Universidade de São Paulo, São Paulo. 102p.

Van Soest P.J., Robertson J.B. \& Lewis B.A. 1991. Symposium: carbohydrate methodology, metabolism, and nutritional implications in dairy cattle. J. Dairy Sci. 74(10):3583-3597. <http://dx.doi.org/10.3168/jds.S00220302(91)78551-2><PMid:1660498> 